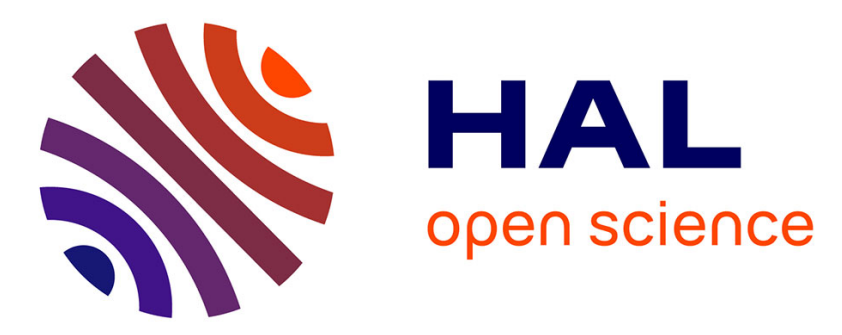

\title{
Hydrangea virescence. II. - Diagnosis by fluorescence microscopy and detection of infection in resin-embedded samples with bright field and phase contrast microscopy
}

Ajay Kumar Sharma, Arnould Savoure, Jacky Rousseau, Marie-Thérèse

Cousin

\section{To cite this version:}

Ajay Kumar Sharma, Arnould Savoure, Jacky Rousseau, Marie-Thérèse Cousin. Hydrangea virescence. II. - Diagnosis by fluorescence microscopy and detection of infection in resin-embedded samples with bright field and phase contrast microscopy. Agronomie, 1986, 6 (3), pp.255-263. hal-00884874

\section{HAL Id: hal-00884874 \\ https://hal.science/hal-00884874}

Submitted on 1 Jan 1986

HAL is a multi-disciplinary open access archive for the deposit and dissemination of scientific research documents, whether they are published or not. The documents may come from teaching and research institutions in France or abroad, or from public or private research centers.
L'archive ouverte pluridisciplinaire HAL, est destinée au dépôt et à la diffusion de documents scientifiques de niveau recherche, publiés ou non, émanant des établissements d'enseignement et de recherche français ou étrangers, des laboratoires publics ou privés. 


\title{
Hydrangea virescence. II. - Diagnosis by fluorescence microscopy and detection of infec- tion in resin-embedded samples with bright field and phase contrast microscopy
}

\author{
Ajay Kumar SHARMA, Arnould SAVOURE, Jacky ROUSSEAU $\left({ }^{*}\right)$ \& Marie-Thérèse COUSIN \\ I.N.R.A., Station de Pathologie végétale, Route de Saint-Cyr, F 78000 Versailles \\ (*) Chambre d'Agriculture de l'Ile-de-France, 2, avenue Jeanne-d'Arc, F 78150 Le Chesnay
}

\begin{abstract}
We have investigated the mild virescence disease of Hydrangea macrophylla by the use of the fluorochrome bisbenzimid $\mathbf{H}$, Hoechst reagent 33258 . In the sieve tubes of virescent plants, brilliant white-blue fluorescence was observed under ultra-violet light. In the corresponding parts of normal plants no such fluorescence could be detected. Blue and ultra-violet light gave complementary information. Sections were observed unstained and stained with the fluorochrome for comparative studies. Abnormal sieve tubes in unstained preparations manifested diffused primary fluorescence. The fluorochrome showed bright fluorescence indicating the presence of DNA-containing structures in the diseased sieve tubes. When the sieve tubes were not fully packed with these structures, epifluorescence resolved them as isolated granules. In order to select the suitable areas in resinembedded samples, thionin-acridine orange staining was found desirable. In $1.0 \mu \mathrm{m}$ thick sections, the infected sieve tubes and the structures contained in them were stained blue-green with thionin. Acridine orange gave better contrast between the cell-wall and inner contents.
\end{abstract}

Additional key words : Light microscopy, Hoechst reagent, thionin, acridine orange, MLO, DNA. fluorescence et repérage en lumière normale et en contraste de phases des zones suspectes sur les échantillons inclus dans les résines.

Pour la détection des maladies à MLO, une méthode de microscopie photonique accessible à différents laboratoires est nécessaire. Le diagnostic de ces maladies est rendu plus précis et plus simple grâce à l'utilisation de la microscopie de fluorescence et des fluorochromes spécifiques de l'ADN. Le travail mentionné ici concerne la détection de la virescence de l'hortensia (Hydrangea macrophylla) grâce à l'utilisation d'un fluorochrome : le réactif de Hoechst (bisbenzimid $\mathrm{H}$ réactif 33258 ). Une fluorescence brillante, bleu clair, est observée en lumière ultra-violette dans les tubes criblés infectés des plantes virescentes.

Les zones correspondantes des plantes saines en sont dépourvues. Les observations en lumière bleue et ultraviolette se montrent complémentaires. La fluorescence secondaire, en présence du fluorochrome, a constamment été comparée à la fluorescence primaire (autofluorescence) en l'absence de tout colorant. Le fluorochrome agit spécifiquement sur les particules contenant de l'ADN dans les tubes criblés infectés. La fluorescence primaire correspondante apparaît moins intense. Lors de l'observation de particules à l'état isolé, la fluorescence en lumière réfléchie (épifluorescence) s'avère supérieure à la fluorescence en lumière transmise. Afin de repérer les zones infectées à partir d'échantillons inclus dans la résine, l'utilisation de la coloration de coupes semi-fines de $1 \mu \mathrm{m}$ d'épaisseur par la thionine et l'acridine orange se révèle intéressante. La thionine colore en bleu vert les tubes criblés infectés. Des particules isolées ont pu être observées. L'acridine orange, en augmentant le contraste entre les parois et le contenu des tubes criblés, contribue à faciliter le repérage des zones infectées.

Mots clés additionnels : Hydrangea, microscopie photonique, réactif de Hoechst, thionine, acridine orange, $M L O, A D N$. 


\section{INTRODUCTION}

A simple method for the diagnosis of yellows diseases has long been needed. Such a method should fulfil the following requirements : it should be sensitive, specific, rapid and must avoid the involvement of sophisticated equipment. The method involving transmission of the disease to periwinkle through dodder (COUSIN et al., 1986) may be used for research purposes but not for diagnosis as it is timeconsuming and success in transmission normally remains less than $100 \%$. Serological methods have been used with success when the vector of the disease is well known (CAUDWELL et al., 1982). Otherwise, absorption of antisera is required to reduce anti plant activity (CLARK et al., 1983 ; CLARK \& DAVIES, 1984). Electron microscopy permits study of the ultrastructure of the yellows agents, but the areas observed under the microscope remain limited. Furthermore, this method is time-consuming and is not available in all laboratories.

All these difficulties have led us to develop a light microscopic method. Light microscopy has been applied to detect either DNA (DIJKSTRA \& VAN DER WANT, 1970 ; COUSIN, 1974 ; KARTHA et al., 1975 ; PUROHIT et al., 1978 ; YUAN et al., 1978), DNA and RNA (PETZOLD \& MARWITZ, 1980 $a$; GRUNEWALDTSTÖCKER, 1982) or whole MLOs (DEELEY et al., 1979 ; GHOSH et al., 1984). Methods using fluorescence microscopy have been found more sensitive than those utilizing bright-field microscopy. Unstained sections of diseased tissues could be differentiated from healthy ones by these methods (COUSIN \& GRISON, 1966 ; COUSIN et al., 1968 ; MARWITZ \& PETZOLD, 1980 ; SHEKHAWAT et al., 1981). Recently PETZOLD \& MARWITZ (1984) reported that biogenic amines could be transformed into fluorescing compounds by aldehyde fixative. Fluorochrome aniline blue was used to locate callose in the diseased sieve tubes of yellows-affected plants (HIRUKI \& DiJKSTRA, 1973 ; DiJKSTRA \& HIRUKI, 1974 ; HIRUKI et al., 1974 ; GHOSH et al., 1984). But since callose is also known to be formed in plants as a defensive measure against injury, the presence of callose in the sieve tubes is not sufficient to claim that the disease is of MLO origin. Fluorochromes specific for neither callose nor DNA, as have been used by CARLE (1965), and GosZDZIEWSKI \& PETZOLD (1975), should not be applied to the detection of yellows diseases. During the last decade fluorochromes reacting with nucleic acids have been used to diagnose yellows type diseases. Detection of mycoplasma-like organisms (MLOs) in various yellows-affected plants has been reported while using fluorochromes specific for DNA and RNA (PETZOLD \& MARWITZ, 1979c, 1980b; GRUNEWALDT-STÖCKER, 1982) or specific only for DNA, like auramin O, N.N'-diethylpseudoisocyanine (PETZOLD \& MARWITZ, 1979a, b), DAPI : 4,6-diamidino-2-phenylindole (SEEMÜLleR, 1976 $a, b$; CAZELLES, 1978 ; DOSBA \& LANSAC, 1982 ; PEARSON et al., 1984 ; HIRUKI \& ROCHA, 1984 ; SCHAPER \& SEEMÜLLER, 1984) and bisbenzimid H., Hoechst 33258 reagent (SEEMÜLlER, 1976a ; COUSIN \& JOUY, 1984 ; COUSIN et al., 1985). In the present work, a similar attempt has been made to diagnose the mild virescence disease of hydrangea.
In resin-embedded samples, thionin-acridine orange staining has been used to localize MLOs in diseased Catharanthus roseus (COUSIN \& JOUY, 1984). For similar reasons, and to select the suspected areas for electron microscopic localization of the organisms associated with hydrangea virescence, the same staining has been performed in the present investigations.

\section{MATERIALS AND METHODS}

\section{A. Materials}

Normal and mild virescence-affected Hydrangea macrophylla Thunb. plants were used for the present work. Before 'flowering', the plants were obtained from the nurseries responsible for the 'forcing' described in the previous article (COUSIN et al., 1986).

For light microscopic examination three parts of the flower were selected : pedicels of normal and virescent flowers, midveins of normal and virescent sepals, and axes proliferated through the pistils of virescent flowers. The size of the samples selected depended on the method utilised. For paraffin embedding or freezing microtomy, $5 \mathrm{~mm}$ and for epoxy resin embedding, $1 \mathrm{~mm}$ long pieces containing the vascular tissues were cut.

\section{B. Methods}

\section{Fluorescent microscopy}

\section{a) Fixation}

For freezing microtomy, fresh unfixed or fixed samples were used. The samples were fixed in $3 \%$ glutaraldehyde in $0.1 \mathrm{M}$ cacodylate buffer $(\mathrm{pH} 7.2)$ for $2-3 \mathrm{~h}$ at room temperature and washed 3 times with $0.1 \mathrm{M}$ buffer. Some of these fixed samples were used directly for freezing microtomy and the rest were processed for dehydration and paraffin embedding which also allowed the samples to be stored indefinitely.

\section{b) Sectioning}

$40 \mu \mathrm{m}$ thick sections of fresh or fixed material were cut with the freezing microtome. Serial sections of paraffin-embedded samples were cut at $8 \mu \mathrm{m}$ thickness, with rotatory microtome.

\section{c) Staining of DNA with Hoechst reagent}

A stock solution of fluorochrome bisbenzimid $\mathrm{H}$ (Hoechst reagent) was prepared $50 \mathrm{mg} / 1$ in distilled water. This solution could be preserved at $4{ }^{\circ} \mathrm{C}$ for several months. At the time of use, it was diluted with $0.1 \mathrm{M}$ cacodylate buffer to get a final concentration of the reagent of $1.0 \mathrm{mg} / \mathrm{l}$. Freezing-microtome-cut or deparaffinized sections were stained with the fluorochrome for $15-20 \mathrm{mn}$ at room temperature, washed two times $(2-3 \mathrm{~mm}$ each) with $0.1 \mathrm{M}$ buffer and mounted in glycerine diluted with an equal amount of the buffer. The preparations were made semi-permanent by applying nail polish to the margins of the cover glasses. 


\section{d) Preparation of control for primary fluores-} cence

For comparative studies, slides were also prepared of unstained sections, consecutive to the stained ones.

\section{e) Illumination system}

Transmission and epifluorescence lights were used alternately for comparative studies. Each preparation was examined under ultraviolet and blue light. Optical microscopes and the filters used were :

Wild M-20 optical microscope with transmission fluorescence ; U.V. light - excitation filters UG 1, BG 38, suppression filter GG $13 \mathrm{c}$; blue light - excitation filter BG 12, suppression filter OG 1c.

Leitz Dialux-20 optical microscope with epifluorescence; U.V. light - Block A, excitation filter BP 340-380, separating mirror RKP 400, suppression filter LP 430 ; blue light - Block $\mathrm{H}_{2}$, excitation filter BP 390-490, separating mirror RKP 510, suppression filter LP 515.

Schedule followed for examining the preparations has been illustrated below :

\begin{tabular}{|c|c|c|c|c|c|}
\hline \multicolumn{3}{|c|}{ Normal sample } & \multicolumn{3}{|c|}{ Diseased sample } \\
\hline $\begin{array}{r}\text { Pri } \\
\text { fluor }\end{array}$ & $\begin{array}{l}\text { ary } \\
\text { cence }\end{array}$ & Hoechst + & & $\begin{array}{l}\text { nary } \\
\text { scence }\end{array}$ & Hoechst + \\
\hline $\begin{array}{l}\text { U.V. } \\
\text { light }\end{array}$ & $\begin{array}{l}\text { blue } \\
\text { light }\end{array}$ & $\begin{array}{ll}\text { U.V. } & \text { blue } \\
\text { light } & \text { light }\end{array}$ & $\begin{array}{l}\text { U.V. } \\
\text { light }\end{array}$ & $\begin{array}{l}\text { blue } \\
\text { light }\end{array}$ & $\begin{array}{l}\text { U.V. } \\
\text { light }\end{array}$ \\
\hline
\end{tabular}

\section{Ordinary light microscopy (staining with thionin- acridine orange)}

Among the different stains that can be used in synthetic resin-embedded materials, thionin-acridine orange stains were selected for the present work. The stains first used by SIEVERS (1971) on animal tissues and by PAUL (1980) on plant material have also been reported to show satisfactory results to detect abnormal phloem sieve tubes suspected to contain MLOs (COUSIN \& JOUY, 1984).

Samples were prepared for observations in the following way :

\section{a) Fixation}

1-mm long pieces of flower pedicel of virescent and normal hydrangea plants were cut in glutaraldehydeparaformaldehyde fixative prepared in cacodylate buffer. This fixative was replaced by the same fresh fixative with addition of dimethyl sulfoxide. Post fixation was done with osmium tetroxide after several washings of the samples in the buffer. The samples were then again washed with the buffer, dehydrated in ethyl alcohol-propylene oxide series, infiltrated and embedded in Epon (LX-112) resin.

\section{b) Sectioning}

Sections ( 0.5 to $1.0 \mu \mathrm{m}$ thick) were cut using a Reichert OM U2 ultramicrotome, fitted with a glass knife. Mechanical advance was used for sectioning.
The sections were transferred into drops of $0.025 \%$ agar in water, so as to make them adhere to glass slides. These slides were dried and stored at $40{ }^{\circ} \mathrm{C}$, until staining was carried out.

\section{c) Staining}

Staining with thionin and acridine orange was carried out following CousIN \& JOUY (1984). D.P.X. was used as a mounting medium. Preparations were observed under normal and phase contrast light microscopes.

\section{OBSERVATIONS AND RESULTS}

\section{A. Fluorescent microscopy}

\section{Choice of the technical procedure}

The fixative described earlier was found suitable for paraffin-embedded or frozen cut sections. Paraffin sections permitted thorough study of the samples. However, the process required more time than freezing microtomy. U.V. light (Plate I ; and Plate II, figs. 5, $6,8,9)$ produced better results than blue light (Plate II, fig. 7). In U.V. light, DNA showed bright blue fluorescence with a black background, but lignin fluorescence could not be suppressed. Blue light helped to identify different types of cells in a complex tissue. It facilitated the localisation of non-infected sieve tubes. The two lights, when used alternately, were found complementary to one another (Plate II, figs. 7 and 8 ).

Both transmission and epifluorescence light systems were used. However, the latter was found better for observing MLOs as isolated granules. Use of primary fluorescence as control (figs. 1 and 3), in comparison to secondary fluorescence (figs. 2 and 4), indicated that the acquired fluorescence by the latter was due to the fluorochrome that reacted with DNA. In fact, primary fluorescence could be seen inside some of the sieve tubes which were completely filled with DNA (fig. 3), but the intensity of fluorescence was enhanced when the fluorochrome was used (fig. 4). Moreover, isolated MLO particles could be detected only when Hoechst reagent was used.

\section{Description of diseased hydrangea sieve tubes}

Virescent Hydrangea plants selected for examination showed fluorescence in the phloem sieve tubes. In normal plants this fluorescence could not be detected (Plate I, figs. 1 and 2). In longitudinal sections, a considerable number of sieve tubes appeared like articulated bones of vertebrate animals (Plate II, figs. 5 and 6). Fluorescence could be seen in the whole sieve tube or was restricted to some parts of it, mainly in the vicinity of sieve plates. Detection of individual particles was possible where the sieve tubes were not completely packed with these DNA-containing structures, and when the level of sectioning was through the centre of the longitudinal axis of the sieve tube (Plate II, fig. 9). As the lumen of hydrangea sieve tube is about $10 \mu \mathrm{m}$ wide, we can assume that sections thinner than $10 \mu \mathrm{m}$ passed through the tube. 


\section{B. Normal light microscopy}

Resin-embedded, semithin cut and thionin-acridine orange stained sections (Plate III) were observed under ordinary and phase-contrast light microscopes. The cell wall was seen to have the colour of acridine orange while DNA and other cell contents were stained with thionin. The lumen of healthy mature sieve tubes remained unstained (fig. 12) while the similar part of the diseased ones, filled with the particles, was stained with thionin (figs. 10 and 11). Difficulties in differentiation occurred when there were very few particles or when the sieve cells were immature and contained nuclei and other cell organelles. Differentiation was easier with mature sieve tubes and high concentrations of the particles. Thinness of the section further added to identification. In addition to DNA, other cell contents were also stained with thionin as the stain is not DNA-specific. The use of acridine orange stain, in spite of producing a better contrast between the cell wall and cell contents, was not always necessary to locate the abnormal sieve tubes. The results have been presented in table 1 .
TABLE 1

Staining of suspected MLOs and cell constituents with thioninacridine orange : comparison of colours in ordinary and phase contrast light.

Coloration des présumés $M L O$ et des constituants cellulaires par la thionine-acridine orange : comparaison des colorations obtenues en lumière ordinaire et en contraste de phase.

\begin{tabular}{|c|c|c|}
\hline \multirow{2}{*}{$\begin{array}{l}\text { DNA containing structures } \\
\text { (suspected MLOs) } \\
\text { and } \\
\text { cell-constituents }\end{array}$} & \multicolumn{2}{|c|}{$\begin{array}{l}\text { Thionin-acridine orange staining } \\
\text { in virescent Hydrangea sieve tubes }\end{array}$} \\
\hline & $\begin{array}{l}\text { bright field } \\
\text { microscopy }\end{array}$ & $\begin{array}{l}\text { phase contrast } \\
\text { microscopy }\end{array}$ \\
\hline $\begin{array}{l}\text { DNA containing structures } \\
\text { (suspected MLOs) } \ldots \ldots \ldots\end{array}$ & light blue-grey & blue-green \\
\hline Cell wall $\ldots \ldots \ldots \ldots \ldots$ & bright yellow & brick red \\
\hline Cell membrane.. & light blue-grey & blue-green \\
\hline Plastid membrane & light blue-grey & blue-green \\
\hline Starch grains .... & pale yellow & orange \\
\hline Nucleoplasm & light blue-grey & blue-green \\
\hline Nucleolus ... & blue-purple & blue black \\
\hline
\end{tabular}

\section{Plate I}

Fluorescent light microscopic observations on normal and virescent Hydrangea macrophylla : primary and secondary fluorescence. $40 \mu \mathrm{m}$ thick longitudinal sections of flower pedicel cut with freezing microtome and observed under the transmission fluorescent microscope using ultra-violet light (excitation filter $U G 1, B G 38$; suppression filter $G G$ 13c).

Observations d'hortensias sain et virescent au microscope photonique à lumière fluorescente. Fluorescences primaire et secondaire. Sections longitudinales $40 \mu \mathrm{m}$ d'épaisseur de pédoncules floraux obtenus à l'aide d'un microtome à congélation et observées avec un microscope à fluorescence en lumière transmise. Lumière ultraviolette (filtres d'excitation UGI, BG38, filtre d'arrêt GGI3c).

\section{Figs. 1, 2}

Normal Hydrangea ; hortensia sain.

1 : Primary fluorescence in part of the stele; diffused auto-fluorescence in the phloem region $(x 660)$.

Fluorescence primaire d'une partie du cylindre central. On observe une autofluorescence diffuse de la zone du phloème $(\times 660)$.
2 : Secondary fluorescence after staining with DNA-specific fluorochrome Hoechst reagent 33258 ; nuclei showing bright fluorescence ( $\times 330)$.

Fluorescence secondaire obtenue à l'aide d'un fluorochrome spécifique de l'ADN: le réactif de Hoechst (33258). Les noyaux montrent une fluorescence nette et brillante $(\times 330)$.

Figs. 3, 4

Virescent Hydrangea ; hortensia virescent.

3 : Primary fluorescence in part of the stele; affected sieve tubes showing enhanced auto-fluorescence $(\times 660)$.

Fluorescence primaire d'une partie du cylindre central. Renforcement de l'autofluorescence des tubes criblés $(\times 660)$.

4: Secondary fluorescence obtained by staining with the fluorochrome: affected sieve tubes show bright white-blue fluorescence; fluorescing DNA-containing structures isolated in one sieve tube element (st a) and completely packed in another (st b), ( $\times 330)$.

Fluorescence secondaire obtenue avec le fluorochrome. Les tubes criblés infectés présentent une brillante fluorescence bleu-clair. Remarquer la présence de particules isolées contenant de l'ADN à l'intérieur d'un tube criblé (sta) et d'un amas compact d'ADN dans un autre tube criblé $(s t b)(\times 330)$. 

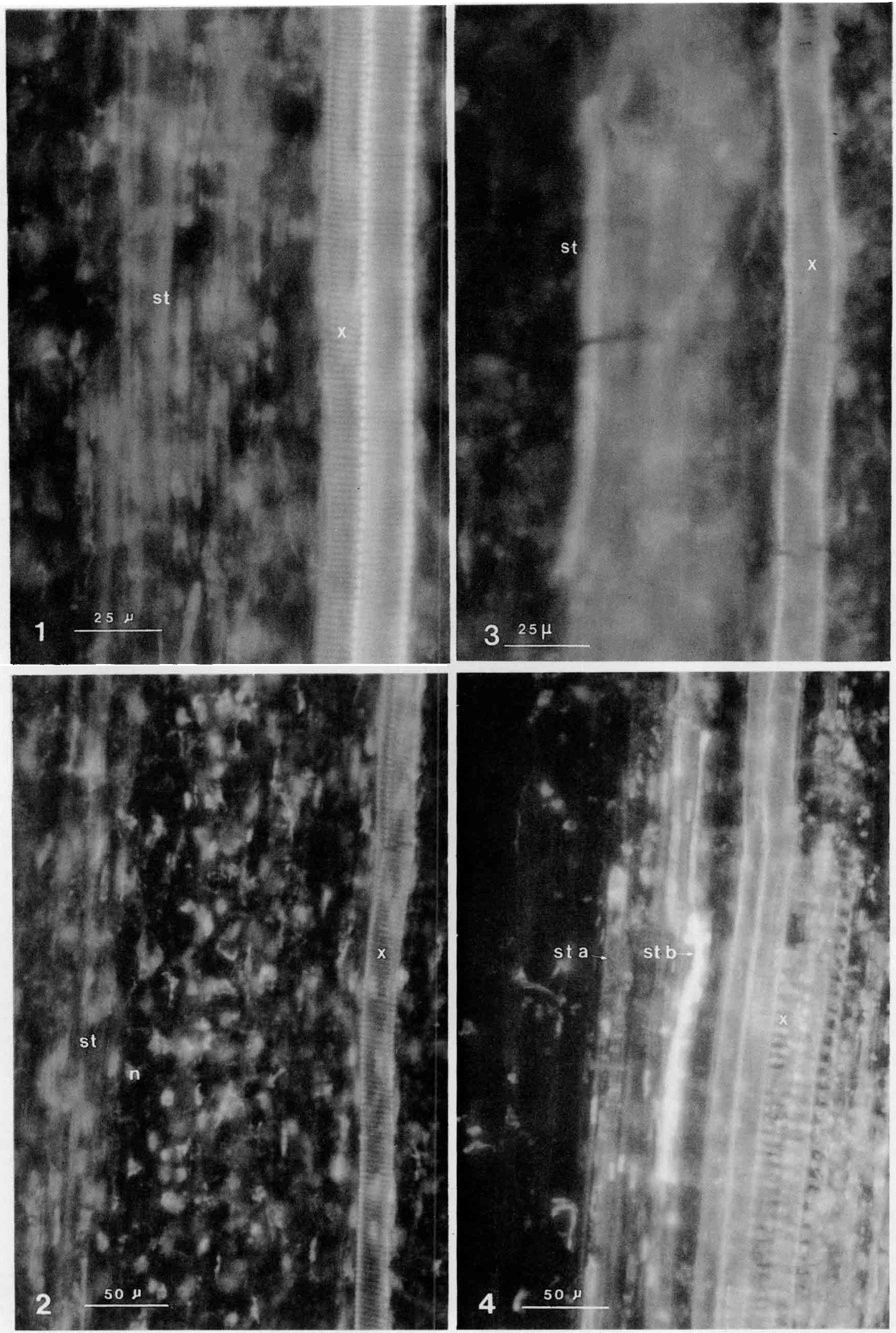


\section{DISCUSSION}

The fluorochrome bisbenzimid $\mathrm{H}$ has shown convincing results for diagnosis of the virescence disease of Hydrangea. Therefore, its use can be recommended to the horticulturists concerned. Suspected virescent Hydrangea mother plants should be eliminated before developing for commercial purposes.

The use of a DNA-specific fluorochrome appears to be the most suitable and reliable method for routine diagnosis of yellow diseases. The method is sensitive enough to detect even mild infection. In addition, after the fixation in glutaraldehyde, the material can be kept safely, either in the buffer solution at $4{ }^{\circ} \mathrm{C}$ for several weeks, or in paraffin for indefinite period.

With a freezing microtome, it is difficult to obtain serial sections of cells in monolayer thickness. Observations on superimposed cell-layers may lead to misinterpretations. For routine diagnosis of yellows diseases by fluorescent light, the cryomicrotome is a better device than the freezing microtome as it helps to obtain serial sections of appropriate thickness allowing a more complete, rapid and reproducible diagnosis.

The fluorescent light microscope method had, however, some limitations, particularly when the DNA-containing particles were present in young sieve cells. Since mature sieve cells were without nuclei and contained no or only a few DNA-containing cell organelles, it is obvious that any amount of fluorescence was the result of interaction between the fluorochrome and the DNA abnormally present in the sieve tube. In contrast, affected immature sieve cells, in addition to MLOs, also had nuclei and a number of DNA-containing organelles. The Hoechst reagent reacted with all these structures, hence the fluorescence observed under the microscope could not solely be attributed to MLOs. Although comparative studies with normal corresponding parts were made, the difference in the amount of fluorescence in young sieve cells was not decisive. In all such cases, it became necessary to confirm the results under the transmission electron microscope.

Detection of abnormal sieve tubes using the thioninacridine orange staining procedure showed advantages over the fluorescence method as semithin sections of resin embedded samples could be used. But thioninacridine orange staining did not provide specificity to the test for the diagnosis of Hydrangea virescence because neither of the stains used was specific to DNA. When compared to the fluorescence method, the latter proved to be considerably more sensitive, convenient and reliable. The merit of using thioninacridine orange stains lies in the fact that it helped to locate the infected areas in resin-embedded samples. After selecting the suspected areas, the samples were used for electron microscopic examination. Electron microscopic studies on the mild type of Hydrangea virescence confirmed the presence of typical mycoplasma-like organisms in phloem sieve tubes. (COUSIN \& SHARMA, 1986.)

Reç le 29 mai 1985. Accepté le 24 octobre 1985.
Plate II

Fluorescent light microscopic observations on Hydrangea macrophylla virescence : secondary fluorescence.

Observations d'hortensias virescents au microscope photonique à lumière fluorescente : fluorescence secondaire.

Figs: 5,6

$40 \mu \mathrm{m}$ thick sections of diseased floret pedicels cut with freezing microtome and observed under ultra-violet light.

Sections longitudinales de $40 \mu \mathrm{m}$ d'épaisseur de pédoncules floraux obtenus à l'aide d'un microtome à congélation et observées avec un microscope à fluorescence en lumière ultra-violette :

5 : Observations under epifluorescent light microscope. Elements of a sieve tube completely packed with DNA particles show white blue fluorescence, with more fluorescence in vicinity of sieve plates. (Excitation filter BP 340-380, separating mirror RKP 400, suppression filter LP 430) ( $\times$ 660).

Observation au microscope à fluorescence en lumière réfléchie (épifluorescence). Eléments de tubes criblés totalement remplis de particules de DNA présentant une brillante fluorescence d'un bleu clair. La fluorescence est particulièrement intense au voisinage de la paroi criblée des tubes (filtre d'excitation BP 340-380, miroir séparateur RKP 400, filtre d'arrêt LP 430) (× 660).

6 : Observations under transmission fluorescent light microscope. Bright white blue fluorescence in several affected sieve tubes, boneshaped sieve tube elements. (Excitation Filter UG 1, BG 38, suppression filter $G G 13 c)(\times 660)$.

Observation au microscope à fluorescence en lumière transmise. Brillante fluorescence d'un bleu clair de plusieurs tubes criblés. La conformation de certains de leurs éléments rappelle celle des os de vertébrés (filtres d'excitation UG1, BG38, filtre d'arrêt $G G 13 \mathrm{c}$ ) $(\times 660)$.

Figs. 7, 8, 9

$8 \mu \mathrm{m}$ thick longitudinal sections of paraffin-embedded diseased floret pedicels observed under epifluorescent light microscope.
Sections longitudinales de $8 \mu m$ d'épaisseur de pédoncules floraux inclus dans la paraffine observées au microscope à fluorescence en lumière réfléchie (épifluorescence).

7: Phloem area when observed under blue light. The use of blue light helps in the identification of various cells in a complex tissue. (Excitation filter BP 390-490, separating mirror RKP 510, suppression filter $L P 515)(\times 660)$.

Zone du phloème observée en lumière bleue: l'utilisation de la lumière bleue peut aider dans l'identification des différentes cellules d'un tissu complexe (filtre d'excitation BP 390-490, miroir séparateur RKP 510, filtre d'arrêt LP 515) (× 660).

8: Same area of phloem, when observed under ultra-violet light. $U . V$. light, which eliminated the unwanted fluorescence other than that of DNA, resulted into a better contrast making the study of $D N A$ containing fluorescing parts easier. (Excitation filter BP 340 380 , separating mirror RKP 400, suppression filter LP 430) (× 660).

Même zone observée en lumière ultra-violette: La lumière ultra violette élimine le bruit de fond résultant de la fluorescence d'éléments cellulaires autres que l'ADN. II en résulte un meilleur contraste qui facilite l'étude des zones fluorescentes contenant l'ADN (filtre d'excitation BP 340-380, miroir séparateur RKP 400, filtre d'arrêt $L P 430)(\times 660)$.

9: Part of sieve-tube element under U.V. light showing fluorescent DNA-containing particles in isolation. (Excitation filter BP 340-380, separating mirror RKP 400, suppression filter $L P 430)(\times 1640)$. $(n:$ nucleus, sp : sieve plate, st : sieve tube, $x: x y l e m, \rightarrow: D N A-$ containing particles in isolation).

Portion d'un élément de tube criblé montant des particules isolées contenant de l'ADN ( $\rightarrow$ ), observées en lumière ultra-violette (filtre d'excitation BP 340-380, miroir séparateur RKP 400, filtre d'arrêt $L P 430)(\times 1640)$

( $n$ : noyau, sp : paroi criblée du tube, $x: x y l e ̀ m e,-$ : particules isolées contenant de l'ADN). 


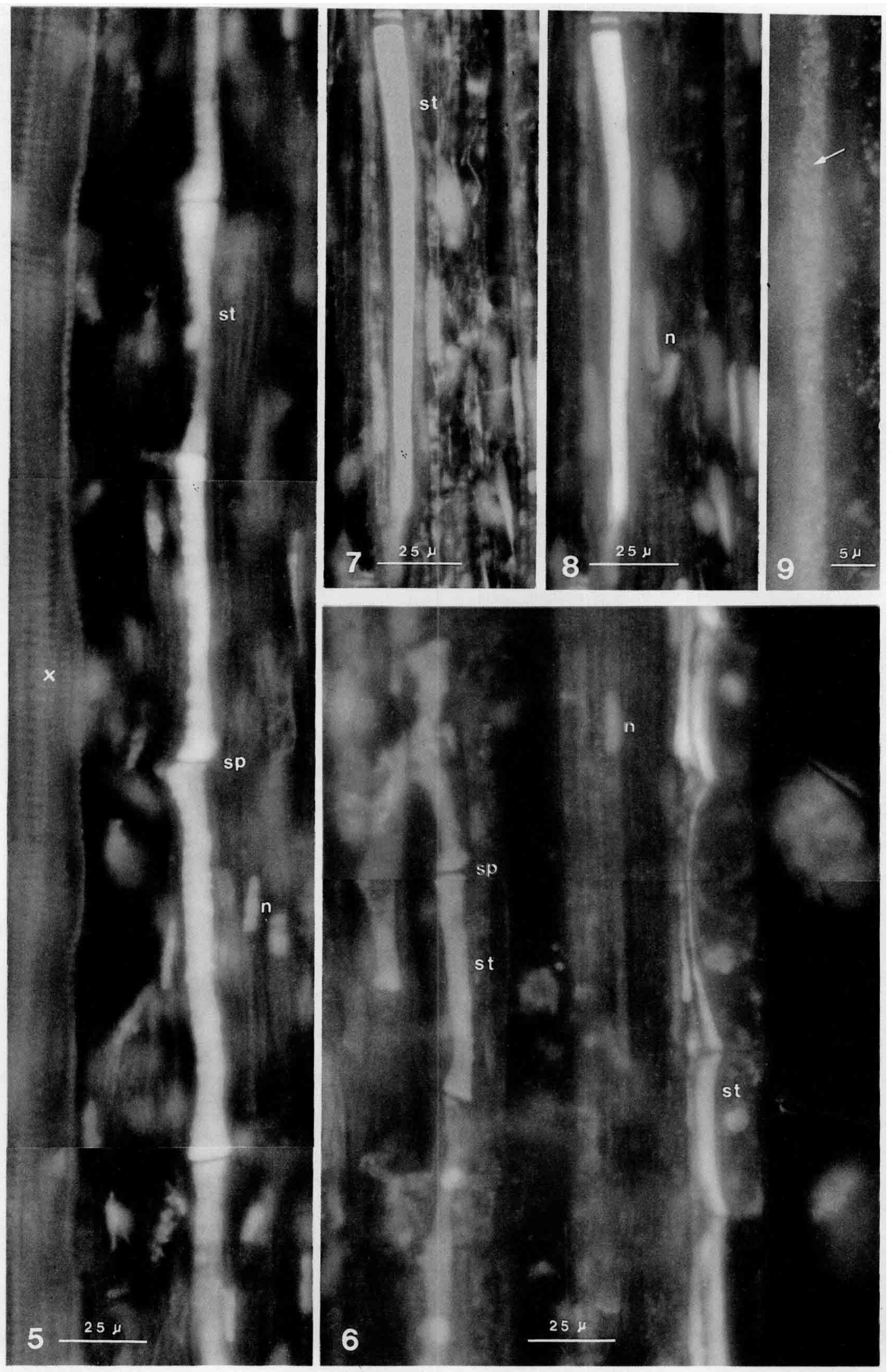




\section{REFERENCES BIBLIOGRAPHIQUES}

Carle P., 1965. Fluoroscopic des symptômes histologiques de la flavescence dorée de la vigne. Application à la détection rapide des lésions précoces sur cépage sensible (Baco $22 \mathrm{~A}$ ). Ann. Epiphyt., 16, N.H.S., 16, 73-85.

Caudwell A., Meignoz R., Kuszana C., Larrne J., Fleury A., Boudon E., 1982. Purification sérologique et observation ultramicroscopique de l'agent pathogène (M.L.O.) de la flavescence dorée de la vigne dans les extraits liquides de fèves (Vicia faba L.) malades. C.R. Soc. Biol., 176, 723-729.

Cazelles O., 1978. Mise en évidence, par fluorescence, des mycoplasmes dans les tubes criblés intacts isolés des plantes infectées. Phytopathol. Z., 91, 314-319.

Clark M. F., Davies D. L., 1984. Mycoplasma detection and characterization. Rep. East Malling Res. St. for 1983 », Maidstone, Kent U.K., 108-109.

Clark M. F., Barbara D. J., Davies D. L., 1983. Production and characteristics of antisera to Spiroplasma citri and clover phyllodyassociated antigens derived from plants. Ann. Appl. Biol., 103, 251259.

Cousin M. T., 1974. Contribution of electron microscopy and photonic microscopy to the study of plant mycoplasmas. Coll. I.N.S.E.R.M. (Institut National de la Santé et de la Recherche Médicale), 33, 223-229.

Cousin M. T., Grison C., 1966. Primary observations on abnormal fluorescence in the internal liber of several Solanaceae infected with the stolbur virus and of an apocynaceous plant attacked by phyllody. Ann. Epiphyt., N.H.S., 17, 93-98.

Cousin M. T., Jouy P., 1984. Comparative study of methods using Hoechst reagent and polychromatic staining for the detection of mycoplasma-like organisms in plants. Agronomie, 4 (4), 341-346.

Cousin M. T., Grison C., Decharme M., 1968. Comparative study of different types of wilting among Solanaceae. Polyphagy of the stolbur. Histological study. Ann. Epiphyt., N.H.S., 19, 121-140.

Cousin M. T., Sharma A. K., 1986. Association of Mycoplasmalike Organisms (MLOs) with mild type of Hydrangea virescence : a study with 60-1 $000 \mathrm{~nm}$ thick sections. Phytopath. $Z$. (in press).

Cousin M. T., Sharma A. K., Rousseau J., Savoure A., Poitevin J. P., 1985. Les différentes étapes du diagnostic d'une maladie à M.L.O. (Mycoplasma-like organisms). Un exemple : La virescence de l'hortensia. C.R. Ire Journ. "Maladies Plantes. "Versailles, ANPP, 2, 223-230.
Cousin M. T., Sharma A. K., Rousseau J., Poitevin J. P., Savoure A., 1986. Hydrangea virescence : I. - Description of the disease and its transmission to the differential host plant Catharanthus roseus by Cuscuta subinclusa. Agronomie 6 (3), 23-28.

Deeley J., Stevens W. A., Fox R. T. V., 1979. Use of Dienes' stain to detect plant diseases induced by mycoplasma-like organisms. Phytopathology, 69, 1169-1171.

Dijkstra J., Hiruri C., 1974. A histochemical study on sandal (Santalum album) affected with spike disease and its diagnostic value. Neth. J. Plant. Pathol., 80, 37-47.

Dijkstra J., Van der Want J. P. H., 1970. Anatomical aspects of sandal plants affected with spike disease. Neth. J. Plant Pathol., 76, 174-178.

Dosba F., Lansac M., 1982. Détection des organismes de type mycoplasme chez les espèces fruitières au moyen du test D.A.P.I. $2^{e}$ Coll. Rech. Fruitière, Bordeaux, 247-257.

Ghosh S. K., Mohamed Ali M. I., Balasundaran M., 1984. Light and fluorescent microscopic studies on little leaf disease of eucalypts. Phytopathol. Z., 110, 207-212.

Goszdziewski M., Petzold H., 1975. Fluorescent techniques to determine presence of mycoplasma-like organisms in plants. Phytopathol. Z., 82, 63-69.

Grunewaldt-Stöcker G., 1982. Light microscopic detection of mycoplasma-like organisms in rooted cuttings of Catharanthus roseus. Zeitschrift für Pflanzenkrankheiten und Pflanzenschutz, 89 (11). 654-661.

Hiruki C., Dijkstra J., 1973. Light and electron microscopy of Vinca plants infected with mycoplasma-like bodies of the sandal spike disease. Neth. J. Plant Pathol., 79, 207-217.

Hiruki C., Rocha A. Da., 1984. The use of fluorescent DNAbinding agent, $4^{\prime}, 6$-diamidino-2-phenylindol (DAPI), for detecting mycoplasma infections in Vinca rosea (Abstr.). Can. J. Plant. Pathol., 6, 262.

Hiruki C., Giannotti J., Dijkstra J., 1974. A comparative study of fluorescence in stems of Vinca rosea infected with mycoplasmas of different plant origins. Neth. J. Plant Pathol., 80, 145-153.

Kartha K. K., Cousin M. T., Ruegg E. F., 1975. A light microscopic detection of plant mycoplasma infection by Feulgen staining procedure. Indian Phytopathol., 28 (1), 51-56.
Plate III

Phase contrast light microscopic observations on normal and virescent Hydrangea macrophylla : Epon-embedded, semithin $(1.0 \mu \mathrm{m})$ cut sections stained with thionin-acridine orange.

Observations d'hortensias sains et malades en microscopie photonique à lumière normale (contraste de phase) de coupes semi-fines de I um d'épaisseur incluses dans l'épon et colorées avec la thionineacridine orange.

Figs. 10, 11

Diseased Hydrangea ; hortensia malade.

10: Longitudinal section of conducting tissues; infected sieve tubes contain blue-green particles which can be seen in isolation when their concentration is not too high; brick-red-coloured cell wall; blue-green cell membrane; some phloem parenchyma cells contain plastids with blue-green membrane and orange-coloured starch ;young sieve cells possess nuclei with blue-green nucleoplasm and blue-black nucleolus $(\times 1325)$.

Section longitudinale des tissus conducteurs. Tubes criblés infectés contenant des particules d'un bleu-vert qui peuvent être observées isolément dans ces tubes où leur concentration n'est pas trop élevée. Coloration rouge brique de lo saroi du tube. Coloration bleu-vert de sa membrane. Quelques cellules du parenchyme libérien contiennent des plastes dont la membrane est colorée en bleu-vert par la thionine et l'amidon en orange par l'acridine.

De jeunes tubes criblés contiennent des noyaux dont le nucléoplasme est coloré en bleu-vert et le nucléole en bleu sombre ( $\times 1325)$

$11:$ Sieve tubes containing densely packed thionin-stained particles (x 1325).

Tubes criblés infectés contenant d'abondantes particules étroitement serrées les unes contre les autres et intensément colorées en bleu-vert par la thionine ( $\times 1325)$.

Fig. 12

Normal Hydrangea : Longitudinal section through conducting tissues; lumen of phloem sieve tube elements devoid of particles (X 1325).

Hortensia sain. Section longitudinale des tissus conducteurs. La lumière des éléments du tube criblé est dépourvue de particules $(\times 1325)$.

( $n$ : nucleus ; noyau. $p$ : plastid; plaste. $s p$ : sieve plate ; paroi criblée. st : sieve tube; tube criblé. $x: x y l e m, x y l e ̀ m e ~-~:$ thionin plaste stained particles in isolation; $\rightarrow$ particules isolées colorées par la thionine. 


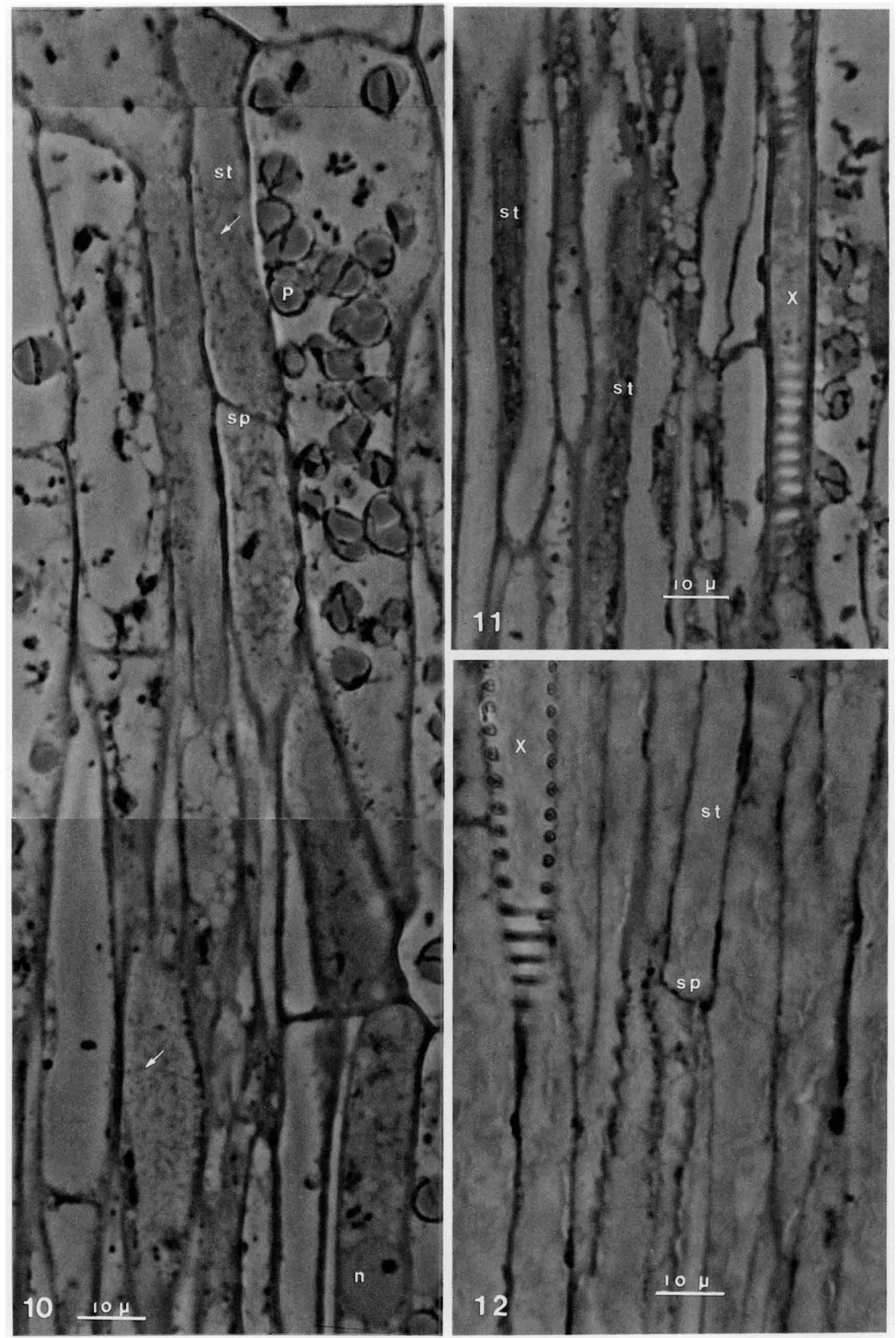


Marwitz R., Petzold H., 1980. A simple fluorescence microscopical method for the detection of infections by mycoplasma-like organisms in plants. Phytopathol. Z., 97, 302-306.

Paul R. N., 1980. The use of thionin and acridine orange in staining semithin sections of plant material embedded in epoxy resin. Stain Technol., 55 (4), 195-196.

Pearson M. N., Keane P. J., Thiagalingham K., 1984. Little leaf : a disease of sweet potato in Papua New Guinea probably caused by mycoplasma-like organisms. Phytopathol. Z., 109, 269-276.

Petzold H., Marwitz R., 1979a. The fluorescence microscopical detection of mycoplasma-like organisms by Feulgen reaction with auramine 0 as Schiff's reagent. Zeitschrift für Pflanzenkrankheiten und Pflanzenschutz, $86(9 / 10), 577-583$.

Petzold H., Marwitz R., 1979b. About the suitability of the fluorescence dye $\mathrm{N}, \mathrm{N}^{\prime}$-diethylpseudoisocyanine chloride for the detection of mycoplasma-like organisms. Zeitschrift für Pflanzenkrankheiten und Pflanzenschutz, 86 (11), 670-674.

Petzold H., Marwitz R., 1979c. Fluorescence microscopical investigations for the detection of mycoplasma-like organisms with the aid of berberine sulphate. Zeitschrift für Pflanzenkrankheiten und Pflanzenschutz, 86 (12), 745-750.

Petzold H., Marwitz R., 1980a. The gallocyanine-chromalum staining for the detection of mycoplasma-like organisms. Zeitschrift für Pflanzenkrankheiten und Pflanzenschutz, 87 (1), 46-50.

Petzold H., Marwitz R., 1980b. An improved fluorescence microscopical detection of mycoplasma-like organisms in plant tissue. Phytopathol. Z., 97, 327-331.
Petzold H., Marwitz R., 1984. Fluorescence of mycoplasmainfected sieve cells after aldehyde fixation. Zeitschrift für Pflanzenkrankheiten und Pflanzenschutz, 91 (3), 286-293.

Purohit S. D., Ramawat K. G., Arya H. C., 1978. Light microscopic detection of mycoplasma-like organism (MLO) in sesamum phyllody. Curr. Sci., 47 (22), 866-867.

Schaper V. U., Seemiiller E., 1984. Effect of the colonization behavior of the apple proliferation and pear decline causal agents on their detectability by fluorescence microscopy. Nachrichtenbl. Deüt. Pflanzenschutz d., 36 (2), 21-25.

Seemüller E., 1976a. Demonstration of mycoplasma-like organisms in the phloem of trees with pear decline or proliferation symptoms by fluorescence microscopy? Phytopathol. Z., 85, 368-372.

Seemüller E., 1976b. Investigations to demonstrate mycoplasmalike organisms in diseased plants by fluorescence microscopy. Acta Hortic., 67, 109-112.

Shekhawat G. S., Khurana S. M. P., Nagaich B. B., 1981. Fluorescence microscopy of potato and tomato plants infected with three mycoplasmal diseases. Zeitschrift für Pflanzenkrankheiten und Pflanzenschutz, 87 (2/3), 148-151.

Sievers J., 1971. Basic two-dye stains for epoxy-embedded 0.3-1 $\mu$ sections. Stain Technol., 46, 195-199.

Yuan S.-L., Song L.-T., Huang Z.-Q., Li X.-S., 1978. A light microscopic detection of M.L.O. associated with Paulownia witches'broom. Acta microbiol. sin., 18 (4), 310-311. 